Albanesi C., Zani B. \& Cicognani E. (2012). Youth civic and political participation through the lens of gender: the Italian case. Human Affairs, 22(3), 360-374.

YOUTH CIVIC AND POLITICAL PARTICIPATION THROUGH THE LENS OF GENDER: THE ITALIAN CASE

\author{
Cinzia Albanesi, Bruna Zani, Elvira Cicognani \\ Department of Education \\ Alma Mater Studiorum, University of Bologna, Italy
}

Corresponding author: cinzia.albanesi@unibo.it 
ABSTRACT: Italy is one of the European countries with the highest levels of gender inequalities (World Economic Forum, 2011). The aims of this paper were to understand to what extent the well-documented gender gap in Italian adult society has an impact on both political and civic actions of younger generations, and whether the process of participation assumes specific features according to gender. 835 Italian participants (49.6\% males; $50.4 \%$ female, aged from 16 to 26 years old; $20 \%$ under voting age) completed a self-administered questionnaire. Analyses confirmed general trends (voting at elections is the most frequently performed political action among Italian youth) and showed the existence of a small gender gap (a major orientation of young women toward civic action, while young men are more engaged in manifest political participation). The results confirmed that family cultural capital and normative support are significant predictors of political participation, in particular for girls and young women.

KEY WORDS: political participation, civic engagement, gender, youth, Italy 


\section{YOUTH CIVIC AND POLITICAL PARTICIPATION THROUGH THE LENS OF GENDER: THE ITALIAN CASE}

\section{Introduction}

According to the data of the World Economic Forum (2011), Italy is one of the European countries with the highest levels of gender inequalities, at the 74th position on the Global Gender Gap Index (out of 135 countries). Italian girls can expect to earn less, to have less important positions in the job market, and to be less represented in politics compared to their male peers (Istat, 2010). Data regarding women in politics are discouraging: even if the number of women in the public administration is growing, their presence in top level positions is very low at national level, both in public administration and in politics. The gender gap is present also in civil society: according to the most recent national survey on volunteers' organizations (Frisanco, 2006), 50\% of the people who are actively engaged in volunteers' organizations are women; women tend to be more involved in voluntary work compared to men, but they occupy leading positions in less than $30 \%$ of cases. Italy is also one of the fastest-ageing societies in the world, with an economy and a political system hardly accessible to young people (Istat, 2010). The general impression that can be drawn from these data is that being young and being female in Italy represent major obstacles to accessing full citizenship and to participating actively in the civic and political arenas.

There is a wide international recognition that today's young generations are less interested in politics compared to previous ones. Two compelling explanations have usually been provided: on the one hand, the lower interest in politics and political participation of younger generations have been explained as a consequence of a more general reduction in political engagement that is common across western countries and across generations (the so called decline thesis); on the other hand, according to the replacement thesis, what seems to be an apparent reduction is instead a transformation of the way political participation is expressed by younger generations. Even if they are more reluctant to join political parties and to be involved in other forms of institutional participation, youth are always attracted by voluntary associations, social movements and other civic groups (O’Toole, Lister, Marsh, Jones, \& McDonagh, 2003; Zukin, Keeter, Andolina, Jenkins, \& Delli Carpini, 2006; Barber \& Torney-Purta, 2009). A recent study of Syversten, Wray-Lake, Flanagan, Osgood and Briddell (2011) provided some support for both theses: analysing cross sectional data collected over 30 years in the US, they found that contemporary generations are less engaged in traditional and 
"unconventional" politics (protest, manifestations), but they are more involved in community service compared to former ones. Regardless of period, the majority of youth declared that they were willing to vote when eligible, but few expressed trust in politicians.

Despite a huge amount of research on civic and political participation in adolescence (Sherrod, Torney-Purta \& Flanagan, 2010), only few studies have tried to assess the presence of gender based differences regarding political participation in younger generations. This is rather paradoxical if one considers that, according to many scholars, levels of political knowledge tend to be stable from adolescence to adulthood (Jennings, 1996) and that they increase the likelihood of future political participation (Gimpel, Lay $\&$ Schuknecht 2003). This suggests that political dispositions are formed early in life and in experiences occurring prior to adulthood (Hooghe \& Stolle, 2004; Atkeson \& Rapoport 2003; Delli Carpini \& Keeter 1996).

A significant exception is represented by the recent work of Cicognani et al. (2012) that examined gender differences in civic and political participation in adolescence, considering the role of parents' political participation, and the mediating role of sense of community and of trust toward institutions in the relationship between civic and social participation and voting intentions. The study confirmed the existence of gender differences in adolescence related in particular to political interest and to the use of the Internet for political participation (both are higher among male youths), but also in social participation. Rainie, Horrigan and Cornfield (2005) found that the Internet has begun to serve as an information resource and as a tool for civic engagement and political participation among young Americans, being used in particular to gather political information. Cassell et al. (2006) suggested that the online world may pull apart gender and traditional leadership, allowing more girls into leading positions and more similarities between boys and girls, reducing many gender stereotypes.

In another recent study conducted in the US, Wolak and McDevitt (2011) confirmed the existence of the gender gap in political knowledge among late adolescents. According to them, the gender gap is not merely a reflection of differences in political dispositions and attitudes of young men and young women, but is a product of fundamental differences in how each gender approaches and responds to its political environment: girls, in particular, would gain more knowledge through a more civic/communal practice of citizenship (in particular when they discuss politics with their family and live in politically homogenous areas), compared to boys; the latter would be more stimulated 
to politics in partisan and competitive environments (see also Hooghe \& Stolle, 2004). Gordon (2008) proposed a similar reasoning: given that boys and girls are "situated" differently at school and in their families, their orientation to civic and political organizations and participation in civic society would depend on the different opportunities that those contexts provide to them to emerge as political actors. Based on the results of a two year ethnographic study, she demonstrated that the family plays a significant role as a "determinant" of young people's political and civic orientation. This is not surprising: there is a huge amount of research that has shown that young people follow their parents' political orientations (McFarland \& Thomaswith, 2006), even if few studies suggest specific gender effects. Cicognani et al. (2012) found a more influential role of mothers compared to fathers, while Matthews, Hempel and Howell (2010) found that family education was more influential in predicting civic participation for girls than for boys.

However, Gordon's results also showed something different: the disparity between boys' and girls' allowed and expected mobility and independence is the cause of the lower ability of girls to become public actors. This perspective, that is compatible with gender role theory (Eagly, 1987; Deaux \& Lewis, 1984; Jost \& Kay, 2005), could probably also explain differences in political participation that still remain later in life (De Piccoli \& Rollero, 2010). Coffé and Bolzendahl (2010) found that women are more likely to engage in "private" activism (according to their definition, this sort of activism includes signing petitions, boycotting products for political reasons, and donate money for social/political reasons), while men are more likely to engage in "public" political kinds of participation and more traditional forms (i.e., membership of political parties). No differences were found concerning voting behaviour. The divide between private and public citizenship has been important in the feminist literature on democratic citizenship (cf. Lister, 2001; Pateman, 1992; Young, 1990) that theorized "second class women's citizenship". According to that perspective, unequal distribution of power between men and women is a consequence of the gendered division of work (see also Galligan, 2010) and of male domination in society.

Bernstein (2005) found consistent gender differences between college students: men reported greater political interest, discussion, and information-seeking compared to women. These differences were related to a reduced exposure to newspapers (but exposure to the Internet was similar for males and females). However, young women who were aware of gender disparity tended to be more politically engaged compared to 
less aware women. Ondercin and Jones-White (2011) found a more nuanced relationship between political knowledge and political participation that reduced the gender gap: less informed women did not participate in politics, but when women had higher levels of political knowledge, they attempted to influence a vote, they attended political meetings, and donated money to a political/social cause like men (see also Barber \& Torney-Purta, 2009). More informed women were also more willing to wear political symbols and to vote, compared to their male peers. Marcelo, Lopez and Kirby (2007) found a somewhat similar pattern in US young adults: young men were more engaged in traditional politics and more informed, while young women were more willing to vote and more involved in activities such as volunteering. Similar findings were also obtained from the secondary analysis of different European and international survey data sets (European Social Survey, ESS; Eurobarometer; International Social Survey Programme ISSP; Comparative Study of Election Systems; Brunton-Smith, 2011) and from the IEA study (Torney-Purta, Lehmann, Oswald \& Schulz, 2001).

Dejaeghere and Hooghe (2009), analysing the data of a nationally representative sample of Belgian adolescents, found that political interest and participation were associated with different concepts of citizenship that in turn differed according to gender: Belgian girls tend to have a more engaged citizenship concept and to be more involved in volunteering compared to boys; the latter had more conventional ideas of citizenship, that were related to political interest. In addition, among girls, in particular religious ones, a law-abiding concept of citizenship was more common compared to boys.

\section{Aims and hypotheses}

The aims of this paper were to understand to what extent the gender gap that has been well documented in Italian adult society has an impact on both political and civic actions of younger Italian generations, and to what extent the process of participation assumes specific features according to gender.

The literature suggests that the gender gap has specific features according to the particular form of participation concerned, suggesting that private forms of participation would be preferred by women compared to public forms. The public/private distinction, however, could be misleading and unable to capture entirely gender differences in political participation and to explain them clearly; similar limitations could be found in all the classifications of forms of participation based on a single criterion (e.g., conventional vs. unconventional; civic vs. political, etc.). 
Recently Ekman and Amnå (2010) proposed the classification of each form of political participation according to two criteria: a latent-manifest dimension (distinguishing between forms of participation that are/are not geared explicitly to affect political decisions and processes) and an individual-collective one (distinguishing between forms of participation that are based on individual actions, performed by a single actor at a time vs. forms of participation that are based on collective actions, performed by a group of people on the basis of a common group identity, aim or ideal).

The literature has not considered specifically gender difference along the latent-manifest dimension of participation; however, it suggests that males will be more orientated towards traditional and confrontational political involvement. We expected to find differences in favour of males regarding political collective manifest participation (H1), differences in favour of females regarding civic engagement and consumerism $(\mathrm{H} 2)$, and similar levels of net participation and voting across genders (H3). The literature has emphasised the gender gap in political interest and knowledge: therefore we expected to find moderate to low levels of interest and knowledge with a small or non significant disadvantage for females (H4), considering the relevance that the web has assumed as a source of political information.

Going to the analysis of the process that leads to political and civic participation, we wanted to test if family education/cultural capital affected participation directly or through parental support/modelling for participation. According to gender role theory and feminist literature on citizenship, this variable should have a different impact on males and females (H5), being higher for females.

Finally, we wanted to test if the family influences (through support for participation) the concept of citizenship in a gendered way. Dejaeghere and Hooghe's (2009) results suggest that the relationship between holding an active concept of citizen and civic engagement could be stronger for females, in particular when they have active parents. Thus, we hypothesised that parental support/modelling for participation would significantly predict civic engagement and political forms of participation other than voting behaviour, through the mediation of an active citizens concept (H6). Finally, we wanted to examine the role of private citizenship in younger generations, considering the amount of responsibilities taken in the private realm as a possible predictor of civic and political participation (H7). From a feminist perspective, private citizenship is traditionally used to legitimate women's absence from the public sphere (i.e., having power/responsibilities at home justifies the fact that women have low levels of public 
power, or are unable to access important public positions). However, it could also be the case that young females that have been more autonomous and active in taking decisions in their private realm would be more willing to engage in the public domain, in particular when they are supported by their parents.

\section{Procedure}

Data collection $^{1}$ took place during 2011. A questionnaire was distributed during class time both in high schools and in universities, with the consent of the teaching authorities. People were recruited in different Italian Regions (Emilia Romagna, Toscana and Campania). The completion of the questionnaire took around 45 minutes. No one refused to participate to the survey.

\section{Participants}

The final sample included 835 Italian participants ${ }^{2}$ (414 males, 421 females, aged from 16 to 26 years old; $M=20.79 ;$ S.D. $=3.08$ ). Voting age was used to distinguish between adolescents and young adults: young people become legally adults (gaining political formal responsibilities and the right to vote) when they turn eighteen. Considering voting vs. non-voting age and gender, the sample was not balanced: non-voting age people (from now on referred to as adolescents) were fewer compared to voting age people (from now on called young adults). $\left(\mathrm{Chi}^{2}{ }_{(1)} 16,251 p=.000\right)$, with fewer adolescent girls $(N=60)$ compared to adolescent boys $(N=105)$; this pattern was reversed among the young adults (young women $N=361$ vs. young men $N=309$ ). The majority of participants $(71.1 \% ; N=591)$ lived with both parents. Only $11.4 \%(N$ =95) lived with one parent. Parent education and cultural capital varied according to age group and gender. A 2 × 2 ANOVA (non-voting vs. voting age $\mathrm{x}$ gender) showed a significant main effect for voting vs. non-voting age group $\left(F_{(1,830)} 16.590, p=.000\right)$ : older participants had more educated families. Cultural capital was measured by asking participants "When you were under 14 years old, about how many books were there in your home?" on a Likert scale from $1=$ none to $6=$ more than 200 . It differed across

\footnotetext{
${ }^{1}$ The empirical research upon which this paper is based was supported by a grant received from the European Commission 7th Framework Programme, FP7- SSH-2007-1, Grant Agreement no: 225282, Processes Influencing Democratic Ownership and Participation (PIDOP) awarded to the University of Surrey (UK), University of Liège (Belgium), Masaryk University (Czech Republic), University of Jena (Germany), University of Bologna (Italy), University of Porto (Portugal), Örebro University (Sweden), Ankara University (Turkey) and Queen's University Belfast (UK).

${ }^{2}$ These people are Italian in the sense that they are born in Italy from native Italian parents: they are full Italian citizens, and they represent the majority sample in PIDOP terms.
} 
gender and group. A 2 × 2 ANOVA (gender x non-voting vs. voting age) showed a main effect of gender $\left(F_{(1,826)} 5.501, p=.019\right)$ and age group $\left(F_{(1,826)} 22,360, p=.000\right)$. Females had more books at home compared to males, and young adults had more books compared to adolescents.

\section{Research Instrument}

The instrument was a self-administered questionnaire, covering the following topics. Political interest, attentiveness and knowledge. Political interest was measured by asking participants their level of agreement on a five-point Likert scale including three items ("I discuss social and political issues with friends and acquaintances", "I bring political and social issues into discussions with others", "I am interested in politics") ( $\alpha$ $=0.87$ ). Political attentiveness was measured by asking for level of agreement on a fivepoint Likert scale with three items ("I follow what is going on in politics by reading articles in newspapers or magazines"; "I watch television programmes or listen to radio broadcasts that deal with political issues", "I pay attention to information about politics on the Internet") taken from Emler (2011) and Zukin et al (2005) $(\alpha=0.79)$. Political knowledge was measured using three items that asked the respondent to choose the correct answer to a set of four questions (the contents of the items were about European Union member states, the differences between democracy and dictatorship, and typical conservative/right-wing political beliefs). A global index of the number of correct answers ranging from 0 to 3 was derived.

Political and civic participation was measured by asking participants how often in the last twelve months they had taken part in a list of civic and political actions ("Visit a website of a political or civic organization", "Link news or music or videos with a social or political content to my contacts", "Wear a bracelet, sign or other symbol to show support for a social or political cause", "Do volunteer work", "Participate in political actions that might be considered illegal", "vote", "boycott or buycott", "Donate money to a social or political cause/organization"). We performed a Principal Component Analysis (using Varimax rotation in order to maximize the interpretability of the factors) on the scale in order to assess its dimensionality ${ }^{3}$, excluding vote and boycott, because we wanted to inspect those items separately. We obtained a three factor solution, explaining $59 \%$ of the variance. The first factor included five items referring to net participation ( $\alpha=0.87$ ); the second one contained three items referring

\footnotetext{
3 Tests of dimensionality and internal consistency of all the scales as reported in the present study pertain only to the Italian sample and not to the international data set from the PIDOP project.
} 
to civic engagement (basically volunteering and supporting social and political causes with money) ( $\alpha=0.48)$, and the third one $(\alpha=0.52)$ items like writing political messages or graffiti on walls, participating in political actions that might be considered illegal, distributing leaflets with a political content, and wearing a bracelet; these items represented a wide range of forms of manifest political participation. Due to lack of internal consistency, we decided to exclude these factors from further analysis and to choose a single item measure of civic engagement (doing volunteer work) and a single item measure of one of the most radical form of manifest political participation (participating in political actions that might be considered illegal). This allowed us to measure and compare four forms of individual participation, two latent forms (interest and attentiveness) and two manifest forms (consumerism and voting), and four forms of collective participation which also consisted of two manifest forms (participating in public meeting and participation in potential illegal actions, representing respectively moderate and extreme forms of manifest political participation) and two latent forms (doing volunteer work and participating on the web).

Parental support for political participation was measured by asking the level of agreement with three items on a five-point Likert scale ("My parents would agree that the only way to change anything in society is to get involved", "My parents would approve it if I engaged politically", "My parents are involved in political actions"). The reliability of the scale was adequate $(\alpha=0.70)$.

Private citizenship was measured by asking about perceived levels of autonomy in different kinds of decisions related to the private realm (contraception, friendship, partner and career), following the suggestion of Menezes, Galligan, Araújo and Lyons (2010) $(\alpha=0.73)$.

To measure the concept of public citizenship, we used a list of items referring to public rights and duties. The PCA produced a two dimension solution that explained $56 \%$ of the variance. The first factor was named law-abiding, because it included the items "obey the law" and "pay taxes" $(\alpha=0.72)$. The item "support women's rights" which loaded on this dimension was excluded because it reduced the reliability of the scale. The second factor was called active citizen because it included items like: a good citizen "enters the army to defend his/her country", "participates in a protest", "promotes human rights" and "votes" $(\alpha=0.66)$. 


\section{Results}

To test the hypothesis concerning gender differences in levels of political and civic participation, including latent and manifest forms of collective and individual participation, a multivariate analysis of variance was performed using a 2 (gender) x 2 (voting vs. non-voting age) design. The multivariate tests showed a gender $\mathrm{x}$ voting vs. non-voting age interaction $\left(\lambda_{\text {Pillai }}=.030 ; F=3,080_{(8,798)} p=.002\right)$ and a main effect of voting vs. non-voting age $\left(\lambda_{\text {Pillai }}=.180 ; F=21,941_{(8,798)} p=.000\right)$ and of gender $\left(\lambda_{\text {Pillai }}\right.$ $\left.=.037 ; F=3,811_{(8,798)} p=.000\right)$

\section{Insert Table 1 here}

Test of between subjects effects showed differences according to gender for levels of volunteer work $\left(F_{(1,802)}=9,612 p=.002\right)$ and participation in potentially illegal actions $\left(F_{(1,802)}=13,831 p=.000\right)$ : the former was higher among females (male $M=1.72$; female $M=2.04$ ) while the latter was higher among males (male $M=1.18$; female $M=$ 1.04). No significant differences were found according to gender in all other forms of participation. The interaction between gender and voting vs. non-voting age group was due to gender differences for political interest $\left(F_{(1,802)}=6,752 p=.01\right)$ and political attentiveness $\left(F_{(1,802)}=7,126 p=.008\right)$ (Table 2$)$. Young women were less politically interested compared to their male peers; the same gender difference, however, was not found among adolescents. A different pattern emerged concerning political attentiveness: male young adults were more attentive compared to young women and to girls, but male adolescents were less attentive.

To test the effect of gender and age on levels of political knowledge, we performed a 2 (gender) x 2 (voting vs. non-voting age) ANOVA. We found a significant interaction effect between gender and age group $\left(F_{(1,831)}=5,149 p=.024\right)$ and a main effect of age group $\left(F_{(1,, 831)}=29,627 p=.011\right)$. Political knowledge increased with age, but this effect was particularly strong for girls: the lowest levels of political knowledge were found among adolescent girls, while the highest levels were found among young women (Table 2).

\section{Insert Table 2 here}

To examine the effect of family education, parental supportive norms and public and private citizenship on civic and political participation, we performed a set of multiple hierarchical regressions entering family education and family cultural capital in the first block, parental norms in the second, and public and private citizenship in the third. Each 
regression was performed separately for males and females, to allow for gender differences. For sake of space, the tables present the statistical parameters of the final models and the significant standardized beta coefficients only.

Process (Hayes, 2012), a computation tool that allows the estimation of direct and indirect effects in multiple mediators models using bootstrap methods, was used to test whether an active citizen concept and private citizenship experiences mediate the relationship between parental support/modelling and civic and political participation. Process was used also to test whether parental support mediates the relationship between parental education and political participation.

If we consider individual latent forms of political participation (Table 3), we observe similar predictors across genders and forms of participation. Supportive parental norms were the most important predictor of political interest $(\beta=.27)$ and attentiveness $(\beta=$ .26) among females, but had a minor though significant role among males. A reverse pattern was observed for the concept of public citizenship: conceiving citizenship as active was more important among males than among females for explaining political interest $(\beta=.23)$ and attentiveness $(\beta=.20)$. Cultural capital predicted interest and attentiveness across genders with only minor differences, while family education seemed to influence political interest $(\beta=.18)$ and attentiveness $(\beta=.15)$ only among males. Cultural capital and private citizenship also predicted male political knowledge; none of the variables included in the regression equation was able to predict females' political knowledge.

\section{Insert Table $3 \& 4$ here}

Cultural capital was the most important predictor of individual manifest participation across genders, in particular in relationship to consumerism. Among females, "active citizen" ideas and parental norms also had significant direct effects on consumerism. "Active citizen" ideas were predictive of manifest and latent collective political participation among males (doing volunteer work excluded); among females they were predictive only of one form of collective participation (net participation) (Table 4).

Supportive parental norms were more important among female participants in order to predict manifest political participation, both at the collective (legal) level $(\beta=.23)$ and at the individual one $(\beta=.17)$. Our research confirmed the gendered role of parental support on civic and political participation, but it did not confirm the mediation role of 
parental support between parental education and political participation, or the mediation role of private and public citizenship between parental support and political participation.

\section{Discussion}

The aims of this paper were to test some hypotheses regarding the gender gap in civic and political participation. We used the typology proposed by Ekman and Amnå (2010) that classifies forms of participations along the latent-manifest dimension and also distinguishes between collective and individual ways of acting politically. This allowed us to differentiate among different forms of participation and to find a more nuanced picture compared to the one that we had hypothesized according to previous studies.

Our results showed that individual forms of participation are generally higher compared to collective ones. The gender gap in political participation among younger generations was confirmed even though it was limited to specific collective forms of participation. Males (as expected according to H1) were more involved in more confrontational forms of participation compared to females, but had the same level of involvement as females in less confrontational form of manifest collective participation (participating in public meetings or demonstrations). Females were more engaged in volunteering (confirming $\mathrm{H} 2$ and the previous results of Marcelo et al., 2007). According to these results, it seems that gender still counts, in particular pulling women away from "radical" collective forms of participation, and assigning to them leading roles in "taking care" of society, reproducing a traditional gender division between maternal and paternal roles at a societal level.

Participation in public meetings/demonstrations was similar across genders; net participation, as expected (H3), was the most popular form of collective participation among our participants in both genders. Probably both forms of participation are related to involvement in social movements and other loosely-organised activities. Regardless of their orientation to political or social ends (Galligan, 2010), they offer a unique opportunity to "taste" how it feels to enter the public scene, without a "definitive" or stable self-identification as a political actor. The web could help both males and females to practice and learn how to become active citizens, as suggested by Cassel et al. (2006). However, it could also facilitate latency in political participation, as it allows people to act in the public arena without leaving their private rooms. 
Going to individual forms of participation, our results confirmed the hypothesis concerning voting (H3): also in this case no gender differences were found. And it is worth noticing that voting was the most popular form of individual manifest political participation, confirming a trend common in other Western societies (Syversten et al., 2011). Contrary to our expectations, we did not find gender differences in levels of consumerism (H2): this is considered to be one of the most typical adult female forms of participation (Coffé \& Bolzendahl, 2010), but in the young generations it is quite common across genders.

Latent individual forms of political participation varied across genders and age groups. In particular, we observed that as females grow up, moving from adolescence to adulthood, their levels of political knowledge increased, cancelling the gender gap (as expected according to $\mathrm{H} 4$ ). The same, however, did not happen with political interest and attentiveness, whose levels were similar across different age groups among females, but not among males, confirming some of Bernstein's (2005) results. This leads to the process of participation. Our results confirmed that family education and cultural capital influence participation directly, as already suggested by McFarland and Thomaswith, 2006). Taken together, these two variables were found to have a significant relationship to all the forms of participation considered, excluding illegal ones, even if female participation seems more affected by cultural capital, while male participation has stronger relationships with family education.

Parental support/modelling for participation, as expected, and according to gendered role theory and the feminist literature on citizenship, impacted directly on political participation more among females (H5) than among their male peers. Citizenship concepts did not play any mediation role between parental support and participation (contrary to H6). However the active citizen concept was found to have significant relationships to all the forms of participation considered except volunteering, in particular among males. Private citizenship was found to be a minor but significant predictor only of individual forms of political participation, and in particular among males, having a very small impact on female political participation (only on voting and net participation). These results provide partial support for $\mathrm{H} 7$, and suggest that males are more prone to participate when they have experienced personal autonomy and have recognized the intrinsic value of active participation. For females, such experiences are not often related to participation. For them, more than for their male peers, political participation is still a matter of family support and of family models. Females need 
more encouragement from their families to act in the public domain: even if they feel as free as their male peers in the private realm, they probably do not feel as free as their male peers when entering the political arena. The Internet in this sense can be an opportunity but also a trap, if people do not move from the virtual to the real public life domain.

Gordon (2008) emphasised the need to increase females' opportunities to emerge as political actors; Cicognani et al. (2012) underlined the influential role of mothers. We propose reconsidering the family as a catalyst for participation, in order to increase female manifest political participation and to reduce the gender gap. This would entail a cultural change in Italy. But such a change could not be accomplished without policies and initiatives capable of reducing structural gender inequalities in the labour market, and promoting equal capacity and opportunity in the Italian society.

\section{Conclusions}

Despite some limitations, related in particular to the sample characteristics (young adults were more numerous compared to adolescents) and to the correlational design that does not allow us to discuss causality, this study provided some support for a gendered approach to political participation in youth studies. Even if gender has a limited effect on political participation in terms of outcome, it is a major source of variation in terms of process. Paths that lead males and females to participate are different, in particular when individual forms of participation are considered: our results suggest that this could be a result of specific gender socialization processes that begin at home. Young people experience and observe gender roles at home, where they are still confronted with (unequal) labour division; at home they start building their (future) political orientations. Gender studies on one side, and research on civic and political participation on the other, both assign a large influence to parents in shaping adolescents' perspectives and behaviours. Our results confirm these assumptions. But of course the family is not the only relevant source of influence in adolescents' experience. The limited variance explained by the multiple regressions suggests the need to include other variables, beyond parental ones, in order to increase the explanatory power of our analysis. Further studies should also consider other proximal contexts (like schools, peer groups, formal groups) that contribute to the formation of citizenship concepts and influence political participation. According to our results, parental norms and citizen concepts have independent effects on political participation. A qualitative approach is 
recommended in order to understand where citizenship concepts come from and the process that leads to their formation, in order to disentangle their specific role in promoting or hindering participation across genders.

\section{References}

Atkeson, L. R., Rapoport, R. B. (2003). The more things change the more they stay the same: Examining gender differences in political attitude expression, 1952-2000. Public Opinion Quarterly, 67, 495-521.

Barber, C. \& Torney-Purta, J. (2009). Gender differences in political efficacy and attitudes to women's rights influenced by national and school contexts: Analysis for the IEA Civic Education Study. In D. Baker and A. Wiseman (Eds.), Gender equality and education from international and comparative perspectives. (pp. 357-394). International Perspectives on Education and Society, Vol 10. Bingley, U.K: JAI/Emerald Group Publishing.

Bernstein, A.J. (2005). Gendered Characteristics of Political Engagement in College Students. Sex Roles, 52 (5/6), 299-310.

Brunton-Smith, I. (2011). PIDOP Work Package 5: Modelling existing survey data, PIDOP Internal Report.

Burns, N., Schlozman, K. L., Verba, S. (1997). The public consequences of private inequality: Family life and citizen participation. American Political Science Review, 91, 373-389.

Cassell, J., Huffaker, D., Tversky, D., Ferriman, K. (2006). The Language of Online Leadership: Gender and Youth Engagement. Developmental Psychology, 42 (3), pp. 436-449.

Cicognani, E., Zani, B., Fournier, B., Gavray, C., Born, M. (2012). Gender differences in youths' political engagement and participation. The role of parents and of adolescents' social and civic participation. Journal of Adolescence, (2011) doi: 10.1016/j.adolescence.2011.10.002. Coffé, H., Bolzendahl, C. (2010). Same Game, Different Rules? Gender Differences in Political Participation. Sex Roles, 62(5), 318-30.

De Piccoli, N., Rollero, C. (2010). Public Involvement in Social and Political Participation Processes: A Gender Perspective. Journal of Community and Applied Social Psychology, 20, $167-183$.

Deaux, K., Lewis, L.L. (1984). Structure of gender stereotypes: Interrelationships among components and gender label. Journal of Personality and Social Psychology, 46, 991-1004.

Dejaeghere, J., Hooghe, M. (2009). Brief report: Citizenship concepts among adolescents. Evidence from a survey among Belgian 16-year olds. Journal of Adolescence, 32, 723-732.

Delli Carpini, M., Keeter, S. (1996). What Americans know about politics and why it matters. New Haven, Yale University Press.

Eagly, A. H. (1987). Sex differences in social behaviour: A social-role interpretation. Hillsdale, NJ: Erlbaum. 
Ekman, J., Amnå, E. (2009). Political Participation and Civic Engagement: Towards A New Typology. Youth \& Society (YeS). Working paper 2 http://www.oru.se/PageFiles/14371/Ekman\%20and\%20Amn\%C3\%A5\%202009-1.pdf

Emler, N. P. (2011). What does it take to be a political actor in a multicultural society? In Martyn Barrett, Chris Flood and John Eade (Eds.), Nationalism, ethnicity, citizenship: Multidisciplinary perspectives (pp. 135-161). Newcastle upon Tyne: Cambridge Scholars.

Flanagan, C., Levine, P., \& Settersten, R. (2009). Civic engagement and the changing transition to adulthood. Medford, MA: CIRCLE

Frisanco, F. (a cura di) (2006). Volontariato sotto la lente. Lo scenario del volontariato organizzato alla luce della Quarta Rilevazione Fivol 2006, Roma: Fondazione Feo-FiVol,.

Galligan, Y. (2010). The Contextual and Individual Determinants of Women's Civic Engagement and Political Participation, PIDOP WP3 Report.

Gimpel, J.G., Lay, C.J., Schuknecht, J.E. (2003). Cultivating Democracy: Civic Environments and Political Socialization in America. Washington, DC: Brookings Institution.

Gordon, H.R. (2008). Gendered Paths to Teenage Political Participation: Parental Power, Civic Mobility, and Youth Activism. Gender \& Society, 22,31-55.

Hayes, A.F. (2012). PROCESS: A Versatile Computational Tool for Observed Variable Mediation, Moderation, and Conditional Process Modeling, submitted for publication.

Hooghe, M., Stolle, D. (2004). Good girls go to the polling booth, bad boys go everywhere: gender differences in anticipated political participation among American fourteen-year-olds. Women \& Politics, 26, 1-23.

Istat (2010). La partecipazione politica: differenze di genere e territoriali, Roma: Istat. Jennings, M.K. (1996). Political knowledge over time and across generations. Public Opinion Quarterly, 60, 228-252.

Jost, J.T., Kay, C.A. (2005). Exposure to benevolent sexism and complementary gender stereotypes: Consequences for specific and diffuse forms of system justification. Journal of Personality and Social Psychology, 88, 498-509.

Lister, M.R. (2001). Gender and citizenship, in K. Nash, A. Scott (eds), The Blackwell Companion to Political Sociology (pp 323-332). Malden: USA, Blackwell,

Marcelo, K. B., Lopez, M. H., Kirby, E. (2007). Civic engagement among young men and women. Medford, MA: CIRCLE.

Matthews, T.L., Hempel, L.M., Howell, F.M. (2010). Gender and the Transmission of Civic Engagement: Assessing the Influences on Youth Civic Activity, Sociological Inquiry, 80 (3), $448-474$.

McFarland, D.A., Thomas, R.J. (2006). 'Bowling Young: How Youth Voluntary Associations Influence Adult Political Participation. American Sociological Review, 71(3):401-425.

Menezes, I., Galligan, Y., Araújo, H., Lyons, E. (2010). Private citizenship scale. 
O’Toole, T., Lister, M., Marsh, D., Jones, S., McDonagh, A. (2003). Tuning out or left out? Participation and nonparticipation among young people. Contemporary Politics, 9(1), 45-61.

Ondercin, H.L., Jones-White, D. (2011). Gender Jeopardy: What is the Impact of Gender Differences in Political Knowledge on Political Participation? Social Science Quarterly, 92(3), 675-694.

Pateman, C. (1992). Equality, difference and subordination: the politics of motherhood and women's citizenship, in G. Bock, S. James (eds). Beyond Equality \& Difference (pp. 17-31). London and New York: Routledge.

Rainie, L., Horrigan, J., Cornfield, M. (2005). The Internet and campaign 2004. Washington DC: PEW Internet and Family Life.

Sherrod, L., Torney-Purta, J., Flanagan, C. (eds.) (2010). Handbook of Research on Civic Engagement in Youth. Hoboken, N.J.: Wiley.

Smith, N.D., Lister, M.R.A., Middleton, S., Cox, L.A.M. (2005). Young people as real citizens: towards an inclusionary view of citizenship, Journal of Youth Studies, 8(4), 425-443.

Syversten A.K., Wray-Lake L., Flanagan C.A., Osgood D.V., Briddell L. (2011). Thirty-Year Trends in U.S. Adolescents' Civic Engagement: A Story of Changing Participation and Educational Differences. Journal of research on adolescence, 21(3), 586 - 594.

Torney-Purta, J., Lehmann, R., Oswald, H., \& Schulz, W., (2001). Citizenship and education in twenty-eight countries: Civic knowledge and engagement at age fourteen. Amsterdam, NL: IEA.

Westman, J. (1991) Juvenile ageism: Unrecognized prejudice and discrimination against the young. Child Psychiatry and Human Development, 21 (4), 237-56.

Wolak, J., McDevitt, M. (2011). The Roots of the Gender Gap in Political Knowledge in Adolescence. Political Behaviour, 33, 505-533.

Young, I. M. (1990). Justice and the Politics of Difference, Oxford: Princeton University Press. Zaff, J. F., Malanchuk, O., Eccles, J. S. (2008). Predicting positive citizenship from adolescence to young adulthood: The effects of a civic context. Applied Development Science, 12, 38-53.

Zukin, C., Keeter, S., Andolina, M., Jenkins, K., Delli Carpini, M. (2005). A new engagement? Political participation, civic life and the changing American citizen. Oxford: Oxford University Press.

Hausmann, R., Tyson, L.D., Zahidi, S. (2011). The Global Gender Gap Report. The World Economic Forum. 
Table 1 Descriptive statistics for the scales used in the present study

\begin{tabular}{|c|c|c|c|c|c|c|}
\hline \multirow[t]{2}{*}{ Scale $^{a}$} & \multicolumn{2}{|c|}{ Male } & \multicolumn{2}{|c|}{ Female } & \multicolumn{2}{|c|}{ Total } \\
\hline & $M$ & S.D. & $M$ & S.D. & $M$ & S.D. \\
\hline Political interest & 2.77 & 1.12 & 2.59 & 0.95 & 2.68 & 1.04 \\
\hline Political attentiveness & 2.59 & 1.10 & 2.51 & 0.98 & 2.55 & 1.04 \\
\hline $\begin{array}{l}\text { Attend a public meeting or demonstration } \\
\text { dealing with political or social issues }\end{array}$ & 1.81 & 1.03 & 1.88 & 1.01 & 1.84 & 1.02 \\
\hline $\begin{array}{l}\text { Boycott or buy certain products for } \\
\text { political, ethical or environmental } \\
\text { reasons }\end{array}$ & 2.04 & 1.39 & 2.16 & 1.34 & 2.10 & 1.37 \\
\hline Vote in elections & 3.07 & 1.77 & 3.19 & 1.75 & 3.13 & 1.76 \\
\hline Net participation & 2.03 & 1.01 & 2.04 & 0.99 & 2.03 & 1.00 \\
\hline Do volunteer work & 1.72 & 1.19 & 2.04 & 1.33 & $1.88 * *$ & 1.27 \\
\hline Participate in potentially illegal action & 1.18 & 0.67 & 1.04 & 0.27 & $1.11 * * *$ & 0.51 \\
\hline Private_citizenship & 4.38 & 0.73 & 4.69 & 0.52 & 4.53 & 0.65 \\
\hline Law-abiding citizen & 4.28 & 0.88 & 4.35 & 0.80 & 4.32 & 0.84 \\
\hline Active citizen & 3.44 & 0.81 & 3.60 & 0.73 & 3.52 & 0.77 \\
\hline Knowledge & 1.83 & 0.80 & 1.92 & 0.82 & 1.87 & 0.81 \\
\hline Parental education & 9.82 & 3.29 & 9.76 & 3.17 & 9.79 & 3.23 \\
\hline Cultural capital & 3.62 & 1.46 & 3.88 & 1.33 & $3.75^{*}$ & 1.40 \\
\hline Parental support & 2.51 & .91 & 2.66 & 0.94 & 2.59 & .93 \\
\hline
\end{tabular}

${ }^{a}$ All the scales range from 1 to 5, except political knowledge $(0-3)$, and parental education $(0$ 18). $* \mathrm{p}<.05, * * \mathrm{p}<.01, * * * \mathrm{p}<.001$

Table 2 Political, interest, attentiveness and knowledge: gender $x$ voting age vs. non voting age interaction

\begin{tabular}{llll}
\hline & & Male & Female \\
& & $M($ S.D. $)$ & $M(S . D)$. \\
\hline Political interest & Non voting age & $2.40(1.06)$ & $2.58(.99)$ \\
& Voting age & $2.88(1.12)$ & $2.58(.95)$ \\
Political attentiveness & Non voting age & $2.10(.99)$ & $2.37(.99)$ \\
& Voting age & $2.74(1.08)$ & $2.53(.98)$ \\
Political knowledge & Non voting age & $1.66(.82)$ & $1.45(.79)$ \\
& Voting age & $1.88(.79)$ & $2.00(.79)$ \\
\hline
\end{tabular}


Table 3 Hierarchical multiple regression: dependent variables: individual forms of participation (standardized beta coefficents)

\begin{tabular}{|c|c|c|c|c|c|c|c|c|c|c|}
\hline & \multicolumn{6}{|c|}{ Individual latent participation } & \multicolumn{4}{|c|}{ Individual manifest participation } \\
\hline & \multicolumn{2}{|c|}{ Political interest } & \multicolumn{2}{|c|}{ Political attentiveness } & \multicolumn{2}{|c|}{ Political knowledge } & \multicolumn{2}{|c|}{ Vote } & \multicolumn{2}{|c|}{ Consumerism } \\
\hline & Male & Female & Male & Female & Male & Female & Male & Female & Male & Female \\
\hline Family education & $.18 * * *$ & & $.15^{* *}$ & & & & $.14 * *$ & & & \\
\hline Cultural capital & $.14 * * *$ & $.16^{* *}$ & $.14 * *$ & $.16^{* *}$ & $.17 * *$ & & $.20 * * *$ & $.13 * *$ & $.30 * * *$ & $.29 * * *$ \\
\hline Supportive norms & $.19 * * *$ & $.27 * * *$ & $.15^{* *}$ & $.26 * * *$ & & & & & & $.17 * * *$ \\
\hline Private citizenship & $.9 *$ & $.10 * * *$ & $.11 *$ & & $.16 * *$ & & $.11 * *$ & $.14 * *$ & & \\
\hline Law abiding citizen & & & & & & & $.11 * *$ & & & \\
\hline Active citizen & $.23 *$ & & $.20 * * *$ & $.10^{*}$ & & & $.14^{*}$ & & & $.11 *$ \\
\hline$R^{2}$ & .24 & .16 & .20 & .14 & .07 & & .16 & .08 & .14 & .16 \\
\hline $\boldsymbol{F}$ & 20.945 & 12.606 & 16.558 & 11.067 & 5.058 & & 11.915 & 5.676 & 10.248 & 13.061 \\
\hline$d f$ & 6,393 & 6,404 & 6,393 & 6,404 & 6,394 & & 6,390 & 6,399 & 6,390 & 6,402 \\
\hline Sign & .000 & .000 & .000 & .000 & .000 & n.s. & .000 & .000 & .000 & .000 \\
\hline
\end{tabular}

$* p<.05 * * p<.01, * * * p<.001$

Table 4 Hierarchical multiple regression: dependent variables: collective forms of participation (standardized beta coefficents)

\begin{tabular}{|c|c|c|c|c|c|c|c|c|}
\hline & \multicolumn{4}{|c|}{ Manifest collective participation } & \multicolumn{4}{|c|}{ Latent collective participation } \\
\hline & \multicolumn{2}{|c|}{$\begin{array}{c}\text { Participation to potentially } \\
\text { illegal actions }\end{array}$} & \multicolumn{2}{|c|}{$\begin{array}{c}\text { Participation to a public } \\
\text { meeting }\end{array}$} & \multicolumn{2}{|c|}{ Net participation } & \multicolumn{2}{|c|}{ Doing volunteer work } \\
\hline & Male & Female & Male & Female & Male & Female & Male & Female \\
\hline Family education & & & $.15^{* *}$ & & $.16^{* *}$ & & $.12 * *$ & \\
\hline Cultural capital & & & & $.12 *$ & $.15^{* *}$ & $.25 * * *$ & & $.13 *$ \\
\hline Supportive norms & $.13^{*}$ & & $.18 * * *$ & $.23 * * *$ & $.17 * * *$ & $.28 * * *$ & & \\
\hline \multicolumn{9}{|l|}{ Private citizenship } \\
\hline Law- abiding citizen & $-.19 * * *$ & & & & & & & \\
\hline Active citizen & $.14^{*}$ & & $.16^{* *}$ & & $.17 * * *$ & $.14 * *$ & & \\
\hline$R^{2}$ & .05 & & .14 & .10 & .20 & .20 & .07 & .02 \\
\hline $\boldsymbol{F}$ & 5.549 & & 10.207 & 7.407 & 16.842 & 16.987 & 4.700 & 2.786 \\
\hline$d f$ & 6,390 & & 6,394 & 6,404 & 6,394 & 6,404 & 6,392 & 3,406 \\
\hline Sign & .000 & n.s. & .000 & .000 & .000 & .000 & .000 & .001 \\
\hline
\end{tabular}

$<.05 * * p<.01, * * * p<.001$ 
